\title{
On the temperature in a final disposal site for high-level radioactive waste
}

\author{
Ute Maurer-Rurack $^{1}$, Guido Bracke ${ }^{1, \mathrm{a}}$, Eva Hartwig-Thurat ${ }^{1, \mathrm{a}}$, Artur Meleshyn ${ }^{2}$, and Torben Weyand ${ }^{1, \mathrm{a}}$ \\ ${ }^{1}$ Federal Office for the Safety of Nuclear Waste Management (BASE), Wegelystrasse 8, 10623 Berlin, Germany \\ ${ }^{2}$ GRS gGmbH, Schwertnergasse 1, 50667 Cologne, Germany \\ aformerly at: GRS gGmbH, Schwertnergasse 1, 50667 Cologne, Germany \\ Correspondence: Ute Maurer-Rurack (ute.maurer-rurack@bfe.bund.de)
}

Published: 10 November 2021

\begin{abstract}
The Site Selection Act stipulates a precautionary temperature limit of $100^{\circ} \mathrm{C}$ on the outer surface of the containers with high-level radioactive waste (HLRW) in the final disposal site. This precautionary temperature limit should be applied in preliminary safety analyses provided that the maximum physically possible temperatures in the respective host rocks have not yet been determined due to pending research.

Increasing temperatures in the deep geological underground, caused by the heat generation of the HLRW, can trigger thermal, hydraulic, mechanical, chemical and biological processes (THMCB) in the respective host rocks of a final disposal site and thus endanger safety. Furthermore, high temperatures may hamper the feasibility to retrieve and recover HLRW from a final disposal site. Such processes are described in detail in databases for features, events and processes (FEP) databases.

Single components or barriers of a final disposal facility may require specific design temperatures for the preservation of their features once a concept for long-term safety of a final disposal site is established; however, the interactions of all relevant processes of a concept for a final disposal site must be considered when a specific temperature limit for the outer surface of the containers is derived. This temperature limit may vary for particular safety and final disposal concepts in the host rock: salt, clay and crystalline rock.

The conclusion is that temperature limits regarding the outer surface of the containers should be derived specifically for each safety and disposal concept and should be supported by a solid safety analysis. Temperature limits without reference to specific safety concepts or the particular design of the final disposal site likely narrow down the possibilities for optimisation and could adversely affect the site selection process in finding the best suitable site.
\end{abstract}

Kurzfassung. Das Standortauswahlgesetz legt eine sicherheitsorientierte Grenztemperatur von $100^{\circ} \mathrm{C}$ an der Oberfläche von Behältern mit hochradioaktiven Abfällen im Endlager fest. Diese Grenztemperatur soll in vorläufigen Sicherheitsanalysen zugrunde gelegt werden, solange die „maximalen physikalischen Temperaturen“ in den Wirtsgesteinen aufgrund ausstehender Forschungsarbeiten noch nicht bestimmt sind.

Der Anstieg der Temperaturen im tiefen geologischen Untergrund, der durch die Wärmeentwicklung der Abfälle bedingt ist, kann hydraulische, mechanische, chemische und biologische Prozesse (THMCB) in den jeweiligen Wirtsgesteinen auslösen und die Sicherheit gefährden. Auch können höhere Temperaturen die Möglichkeiten zur Rückholung oder Bergung von Abfällen aus dem Endlager erschweren. Derartige Prozesse sind bereits detailliert in Datenbanken für Eigenschaften, Ereignisse und Prozesse („FEP databases“) beschrieben.

Für einzelne Komponenten oder Barrieren eines Endlagers können spezifische Temperaturgrenzen erforderlich sein, um den Erhalt ihrer Eigenschaften in einem Konzept für die Langzeitsicherheit zu gewährleisten. Jedoch müssen alle Wechselwirkungen der wichtigsten Prozesse eines Endlagerkonzepts berücksichtigt werden, um einen spezifischen Temperaturgrenzwert für die Behälteroberfläche abzuleiten. Daher kann dieser Temperaturgrenzwert für das jeweilige Sicherheits- und Endlagerkonzept in den Wirtsgesteinen Steinsalz, Tongestein und Kristallingestein unterschiedlich ausfallen. 
Daher ist die Schlussfolgerung, dass ein Temperaturgrenzwert für die Behälteroberfläche spezifisch für jedes Konzept abgeleitet werden und mit einer belastbaren Sicherheitsanalyse belegt sein sollte. Temperaturgrenzwerte ohne Bezug auf ein Sicherheits- und eine spezifische Endlagerauslegung könnten wahrscheinlich die Möglichkeiten zur Optimierung beschränken und das Standortauswahlverfahren im Hinblick auf den bestmöglichen Standort ungünstig beeinflussen. 